\title{
The Utilization of Amino-Acid Solutions by Virus-Infected Eggs, Studied by Paper Ghromatography
}

\author{
BY M. VAN DEN ENDE \\ The Department of Pathology, University of Cape Town
}

SUMMARY : The rate of utilization of amino-acids injected into the allantoic cavity of virus-infected eggs was studied by paper-strip chromatography.

Influenza virus brought about more rapid disappearance of amino-acids from the allantoic fluid than Mumps, Vaccinia or Lumpy Skin viruses or diphtheria and Clostridivem relchii toxins. The utilization of amino-acids appears to be non-specific and not directly concerned with virus synthesis.

Increasing attention is being paid to the chemical processes in virus multiplication. In particular the bacteriophage has been studied (cf. Cohen, 1949). Spizizen (1943) described the effect of certain amino-acids on the release of bacteriophage from infected host cells suspended in simple media. Animal viruses have, however, received relatively little attention, though Bauer (1948) has reported an increase in xanthine oxidase in virus-infected chick embryos and mouse brain.

Paper chromatography (Consden, Gordon \& Martin, 1944) appeared to us to be well suited for studying the utilization of amino-acids and other substrates by virus-infected tissues, and in particular by eggs, which are generally used for the cultivation of animal viruses.

We undertook this work in the hope of discovering differences between the normal and virus-infected eggs which might elucidate the intracellular synthesis of viruses.

\section{METHODS}

Solutions of amino-acids were prepared containing four to six amino-acids which would separate well on simple strip-paper chromatograms with phenol or butanol as solvent. The solutions were made in distilled water, the concentration of each amino-acid being $0.015 \mathrm{M}$, adjusted to a $\mathrm{pH}$ of $c$. 7, Seitz filtered and stored in the dark in small screw-capped bottles.

Eggs incubated for 9 days received $0.2 \mathrm{ml}$. of virus suspension or saline into the allantoic cavity, and were held at $35^{\circ}$. After $1 \frac{1}{2}-18 \mathrm{hr}$. the eggs were opened through a triangular flap over the burr-hole of the inoculation, and the allantoic cavity opened without allowing the chorio-allantoic membrane to drop. The allantoic fluid was pipetted off with sterile precautions and replaced by $2 \cdot 0 \mathrm{ml}$. of amino-acid solution or saline. The triangular opening was closed with cellophan tape. After further incubation for 15-72 hr. each egg was chilled in the ice chest, reopened by cutting away the cellophan window, and the allantoic fluid was collected. The allantoic cavity was then washed with sterile saline and the washings pooled with the original fluid to make a total volume of $10 \mathrm{ml}$. Each pool was tested for sterility and, where practicable, titrated for virus content. 
For strip chromatograms single $1 \frac{1}{1}$ in. strips of Whatman No. 1 filter paper were used. Two volumes of $100 \mu \mathrm{l}$. of fluid from a single egg were then applied to each strip; the second volume after the first had completely dried. A large museum jar and a shallow glass dish made a convenient apparatus to hold up to 16 strips at a time. Temperature was not controlled, but strips with known concentrations of the original amino-acid solution were included in each jar for comparison of colour intensities after development with ninhydrin. Convenient separation was usually obtained in 10-12 hr. at room temperature, after which the strips were dried at $80^{\circ}$ and developed with ninhydrin. In some experiments, filter-paper sheets were substituted for single strips and butanol was used as solvent.

The virus strains used were Influenza A (PR 8 and Lepine), Swine influenza, Mumps (Enders strain), Lumpy Skin Disease and Vaccinia. In addition, diphtheria and Clostridium welchii toxins were tested to determine whether non-specific factors were responsible for the effects observed with viruses.

The dosage of virus or toxin had to be adjusted so that the embryo did not die during the experiment, because post-mortem autolysis resulted in the rapid appearance of amino-acids which obscured those introduced.

\section{RESULTS}

Virus titres of the pools collected were almost invariably low when allantoic fluid was replaced by saline $12 \mathrm{hr}$. or more after infection of the eggs.

The results of typical experiments using one amino-acid mixture are summarized in Table 1. The disappearance of amino-acids from the allantoic cavity of eggs infected with influenza virus is rapid compared with that from control eggs receiving saline instead of virus inoculum, or from eggs infected by other viruses. All the six amino-acids are equally affected and there is no evidence of any selective utilization. Similar results were obtained with mixtures of (a) methionine, hydroxyproline, threonine, serine and valine; and (b) glycine, lysine, leucine and proline. When the period of incubation between virus inoculation and allantoic fluid replacement was $18 \mathrm{hr}$. and the second period of incubation was shortened to $15-18 \mathrm{hr}$. the rapid disappearance of the aminoacids was still demonstrable, but when the interval between infection with influenza virus and the introduction of amino-acids was decreased to $1 \frac{1}{2} \mathrm{hr}$. the accelerated disappearance of the amino-acids in the subsequent $24 \mathrm{hr}$. was no longer striking. This suggests that the effect is non-specific, possibly due to the inflammatory reaction set up by the influenza virus. But the fact that influenza virus infection differed so strikingly from infection by other viruses that are also capable of multiplication in the cells lining the allantoic cavity, and from inflammation produced by toxins in the allantoic fluid, remains unexplained. It is possible that the other infective agents and the toxins under the particular experimental conditions produced a less severe inflammation or that the inflammation was accompanied by different metabolic derangements of the host cells. Such metabolic derangements may be the direct result of the virus infection. 
Material giving positive reaction with ninhydrin occurred in normal as well as in virus-infected eggs, but no attempt was made to identify it.

Table 1

\begin{tabular}{|c|c|c|c|c|c|c|c|c|c|}
\hline \multirow[b]{2}{*}{ Inoculum } & \multirow{2}{*}{$\begin{array}{c}\text { Allantoic } \\
\text { fluids } \\
\text { replaced by }\end{array}$} & \multirow{2}{*}{$\begin{array}{c}\text { Incubation } \\
\text { after re- } \\
\text { placement } \\
(\mathbf{h r} \text {.) }\end{array}$} & \multicolumn{6}{|c|}{$\begin{array}{l}\text { Final contents of allantoic cavity. } \\
\text { Colour intensity of amino-acids on chromatogram* }\end{array}$} & \multirow{2}{*}{$\begin{array}{c}\text { Virus } \\
\text { haema- } \\
\text { glutinin } \\
\text { titre }\end{array}$} \\
\hline & & & $\begin{array}{l}\text { Aspartic } \\
\text { acid }\end{array}$ & $\begin{array}{l}\text { Glutamic } \\
\text { acid }\end{array}$ & Glycine & Alanine & Histidine & $\begin{array}{l}\text { Phenyl- } \\
\text { e alanine }\end{array}$ & \\
\hline Influenza $A$ & $\begin{array}{l}\text { Amino-acids } \\
\text { Amino-acids } \\
\text { Saline }\end{array}$ & $\begin{array}{l}48 \\
48 \\
48\end{array}$ & Tr. & - & Tr. & $\frac{\text { Tr. }}{-}$ & - & $\begin{array}{l}+ \\
+ \\
-\end{array}$ & $\begin{array}{l}1 / 160 \\
1 / 320 \\
1 / 320\end{array}$ \\
\hline ialine & $\begin{array}{l}\text { Amino-acids } \\
\text { Amino-acids }\end{array}$ & $\begin{array}{l}48 \\
48\end{array}$ & $\begin{array}{l}+ \\
+\end{array}$ & $\begin{array}{l}+ \\
+\end{array}$ & + & + & $\stackrel{+}{++}$ & $\begin{array}{l}+ \\
+\end{array}$ & - \\
\hline Lumpy skin & $\begin{array}{l}\text { Amino-acids } \\
\text { Amino-acids }\end{array}$ & $\begin{array}{l}48 \\
48\end{array}$ & $\begin{array}{l}+ \\
+\end{array}$ & $\begin{array}{l}+ \\
+\end{array}$ & $\begin{array}{l}+ \\
+\end{array}$ & $\begin{array}{l}+ \\
+\end{array}$ & $\begin{array}{l}+ \\
+\end{array}$ & $\begin{array}{l}+ \\
+\end{array}$ & 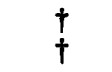 \\
\hline Saline & Amino-acids & 48 & ++ & ++ & ++ & ++ & ++ & ++ & 一 \\
\hline Swine flu & $\begin{array}{l}\text { Amino-acids } \\
\text { Amino-acids }\end{array}$ & $\begin{array}{l}48 \\
48\end{array}$ & $\begin{array}{l}\text { Tr. } \\
\text { Tr. }\end{array}$ & - & - & $\stackrel{+}{+}$ & Tr. & - & $\begin{array}{l}1 / 40 \\
1 / 20\end{array}$ \\
\hline Saline & Amino-acids & 48 & +++ & +++ & $+t+$ & $+t+$ & +++ & +++ & 一 \\
\hline Swine flu & Saline & 48 & - & - & - & - & 一 & - & $1 / 20$ \\
\hline Mumps & $\begin{array}{l}\text { Amino-acids } \\
\text { Amino-acids }\end{array}$ & $\begin{array}{l}72 \\
72\end{array}$ & $\begin{array}{l}+ \\
+\end{array}$ & $\begin{array}{l}+ \\
+\end{array}$ & $\begin{array}{l}+ \\
+\end{array}$ & $\begin{array}{l}+ \\
+\end{array}$ & $\begin{array}{l}+ \\
+\end{array}$ & $\begin{array}{l}+ \\
+\end{array}$ & $\begin{array}{l}1 / 160 \\
1 / 160\end{array}$ \\
\hline Saline & $\begin{array}{l}\text { Amino-acids } \\
\text { Amino-acids }\end{array}$ & $\begin{array}{l}72 \\
72\end{array}$ & + & $\stackrel{+}{+}$ & $\begin{array}{c}+ \\
++\end{array}$ & $\begin{array}{c}+ \\
+\end{array}$ & $\begin{array}{c}+ \\
++\end{array}$ & $\stackrel{+}{++}$ & - \\
\hline Mumps & Saline & 72 & - & - & - & - & 一 & - & $1 / 160$ \\
\hline $\begin{array}{l}\text { Diphtheria } \\
\text { toxinf }\end{array}$ & Amino-acids & 48 & ++ & ++ & + & ++ & + & + & 一 \\
\hline Saline & Amino-acids & 48 & + & ++ & ++ & ++ & + & + & 一 \\
\hline
\end{tabular}

* Tr. = trace of colour.,,$++++++=$ colour intensities corresponding respectively to one-eighth, one-sixth and one-quarter of that given by the original solution of amino-acids.

+ Fuids produced specific death in $100 \%$ of eggs in $3-4$ days.

$¥$ Dose $=0.5$ minimal lethal dose for eggs.

This work was carried out with a grant from the South African Council of Scientific and Industrial Research. Dr F. M. Burnet kindly supplied the strain of Mumps virus used. We are grateful to Dr T. S. Work for some of the chromatograms.

\section{REFERENCES}

BAUER, D. J. (1948). Association of xanthine oxidase with virus multiplication. Nature, Lond., $161,852$.

Cohen, S. S. (1949). Growth requirements of bacterial viruses. Bact. Rev. 13, 1.

Consden, R., Gordon, A. H. \& Martin, A. J. P. (1944). Qualitative analysis of proteins : a partition chromatographic method using paper. Biochem. J. 38, 224.

SpIzizEN, J. (1943). Biochemical studies on the phenomenon of virus reproduction. I. Amino-acids and the multiplication of bacteriophage. J. infect. Dis. 73, 212. 